\title{
Analogy of Kaba Suram with COVID-19 Symptoms - A Siddha Literature Review
}

\author{
Review Article
}

\section{Susila Rathinam ${ }^{*}$, Kannan Muthiah², Sathiyarajeswaran Parameswaran ${ }^{3}$, Kavitha Tamilarasan', Esaivani Selvarajan1, Usha Ayyasamy1}

\author{
1. Research officer (Siddha), Basics and Fundamental Division, Department of Clinical Research, \\ 2. HOD, Literary Research and Documentation Department, 3. Director I/C, \\ Siddha Central Research Institute, Central Council for Research in Siddha, Arumbakkam, Chennai.
}

\begin{abstract}
Kaba Suram (phlegmatic fever) is one among the 64 types of Suram (Pyrexia/fever), its synonyms, causes, pathology and characteristics have been mentioned crystal clear in Siddha literature. Its clinical features have been mentioned in few literatures such as Theran karisal, Suravagadam, Yugi chinthamani etc., which are almost similar to each other. The present day pandemic disease COVID-19 which still lacks specific drug towards its management or prophylaxis has become the spectrum of research focus in current scenario. Upon keen understanding of the Siddha literature the signs and symptoms of Kaba Suram fall in line with COVID-19 and a few other flu like illnesses. Therefore, the herbal decoction Kaba Sura Kudineer (KSK) indicated for the management of Kaba Suram has been recommended by the Siddha research community towards an integrated approach in tackling this worldwide emergency. The current scientific community demands evidence based explanation to understand the concept of Siddha system of medicine and necessitates International standards to reassure the efficacy of Siddha medicine. In this aspect, this review is aimed at evaluating all the available informations on Kaba Suram in Siddha literature and pathophysiology of COVID-19 and to interpret the search results in terms of pathophysiology of Kaba Suram based on Mukkutram theory. This effort would therefore enable the Siddha research community to opt for effective Siddha medicines to manage the present pandemic situation.
\end{abstract}

Key Words: Corona Virus, COVID-19, Traditional medicine, Indian Medicine, Kaba suram.

\section{Introduction}

The Siddha system of medicine is one among the Indigenous medical systems predominantly practiced in South India. The literature of Siddha describes 4448 diseases which can affect the human (Siddha classical text Agathiyar irantaayiram)(1). According to Siddha science, the three subtle entities called Vali (Vatham), Azhal (Pitham), and Aiyam (Kabam) are said to be the three vital life forces / functional units of the human body. These units are responsible for the general health and well being of an individual when they are present in the ratio of $1: 1 / 2: 1 / 4$ respectively(2). Consumption of unhealthy food pattern and habits can alter the ratio of these functional units leading to various ailments (Imbalance of the vital life forces). Suram (Pyrexia/fever) is considered as one of the diseases in Siddha literature which has been classified into 64 types. The causes of Suram are

\section{* Corresponding Author:}

\section{Susila Rathinam}

Research officer (Siddha), Basics and Fundamental division, Department of Clinical Research,

Siddha Central Research Institute, Central Council for Research in Siddha, Arumbakkam,Chennai-106. India Email Id: drsusilasiddha@gmail.com categorized based on the affected Mukkuttram (Vatham, Pitham and Kabam) by means of unhealthy diet and habits.

According to Siddha concept, the etiopathogenesis of Suram (Pyrexia/fever) is due to the formation of Amam (indigested metabolic products) in the intestine favoured by the aggravated Kabam humour. This fact has been emphasized in the Siddha literature as Kudal thannil seetham allaathu Suram varaathu(3). Though unhealthy food habits have been mentioned as a general cause of Suram in majority of selected literatures, it has also included a few practical issues of life towards the etiopathogenesis of fever in common. They are wrong behaviour/ habits, Exposure to excessive and polluted air, walking for a long distance/running hardly, excessive work strain, excessive sexual indulgence, vitiated Vathathodam, fear and worries, insomnia, anger and other bad emotions, vitiated Kabathodam, wandering in mist and excessive chillness, sensation of coldness due to getting wet in rain or bathing for a long time, indigestion and constipation(3-5). The Siddha concept portray that Vatham humour is responsible for conception and creation, Pitham for counter action against diseases and Kabam for annihilation which is emphasized in the lines of Siddhar Theran as "Vaathamai padaithu pitha vanniyai kaathu sethuma seethamai thudaithu." 
Infections and disease progression occur when an individual's immunity is challenged. This immune challenge could be connected with decrease of Pitham. The preliminary symptoms of COVID-19 such as fever, dry cough, sore throat might be overcome if there is acceptable measure of immunity when Pitham humour is energetic. If not the Kaba Thodam raises and further progresses to a critical stage Sanni (Delirium)(3).This literature search would provide information regarding disease staging, prognosis and crucial assessment to choose effective Siddha medicines based on altered humour and aid in the management of COVID-19. This literature analysis has been focused at analyzing, summarizing and correlating all the available informations on Kaba Suram in Siddha literature with that of the various symptoms and pathophysiology of COVID-19 and to derive the Siddha pathophysiology of Kaba Suram based on Mukkutram theory.

The relevant Siddha literatures which has mentioned about the Suram were searched from the Library Unit of Siddha Medicine. Siddha Classical books such as Yugi Vaithya Sintamani, Noi Nadal Noi Muthal Nadal Thiratu (Rendam Paagam), Siddha Maruthuvam (Pothu), Pararasasekaram Sura Roga Nithanam, Theran karisal, Theran yamaka venpa were identified and collected for this study. Web based search was also carried out using biomedical data bases such as Scopus, Embase, Elseivier, medline, web of science , Google scholar etc. All data were collected, tabulated and analysed for analogy with the symptoms of COVID-19. A flow chart based on the Kaba Suram symptoms which parallel with COVID-19 stages was formulated and the Mukkuttram (Trithodam) based patho physiology was concluded.

\section{Kabam and Kaba Suram}

Normally, the predominant seats of Kabam in human body has also been described in literature as the region of thorax above the heart, head, tongue, tonsils, fat, cartilage, blood, nose, chest, nerves, brain, eyes, joints, intestine and semen.(6) Kabam provides support and substance to the body. It structures everything the musculo-skeletal frame both physical and psychological, and governs human emotions such as love, compassion, forgiveness, loyalty, and patience. Kabam can bestow immunity against disease and can act to restrict the two forces Vatham and Pihtam and prevent their excessive manifestation. Any abnormal increase in humour of Kabam would result in aggravated Kaba thodam (Thannilai Valarchi) in the regions of Kabam predominance in the body resulting in ailments. Since Siddha system of medicine deals with the root cause of diseases, the present study Kaba Suram is said to occur due to the aggravated humour of Kabam much more than its normalcy, facilitating a favourable environment for any respiratory infection(1,7,4). The aggravated humour of Kabam lodges in other parts of the body other than its own seats (Vaetrunilai Valarchi).

The above mentioned reasons increases Kabam which fluctuates Kledaka Kabam and results in Amam and fever. This Amam is absorbed by the intestinal vessels and distributed all over the body and obstructs the excretion of sweat resulting in fever. Thus the formation of Amam is the main reason for increasing the body temperature. The common and major symptoms of Kaba Suram mentioned in all the texts are body ache, fever, cough, fatigue, diarrhoea, sore throat, shortness of breath, chest pain and sometimes leading to neurological symptoms like confusion and even death(2).

\section{End stage of Kaba Suram (Sanni - Delirious stage)}

The end stage symptoms of Kaba Suram occur due to vitiation of the Mukkuttram (Vatham, Pitham and Kabam) (the abnormal physiological state). In general the vitiation of Vatham, Pitham and Kabam either singly, dually, or triply results in diseases. In Kaba Suram the end-stage features such as altered mental status, impaired consciousness, irrelevant speech, emotional instability, agitations etc., is said to occur on the derangement of all the three humours ie Vali, Azhal and Aiyam. This stage is termed as Sanni (Delirium) in which quantitative/qualitative changes in Mukkuttram takes place and the nomenclature is made accordingly based on the degree of the involvement of each dosha and the dominant dosha. Therefore the conglomeration of vitiated Mukkuttram is termed as final stage of disease and the presenting illness becomes more advance and mostly irreversible (3).

\section{Seasonal variation}

The Siddha literature also predicts the framework of seasons and the probability of disease occurrence on earth. As the earth resolves around the Sun it gets sunlight at various positions. With reference to the position of the earth towards the Sun, each year is divided into six seasons. They are,

1.Karkaalam-Avani, Puratasi (August, September)

2.Koothirkaalam - Iyppasi, Karthigai (October, November)

3.Munpanikaalam -Margazhi, Thai (December, January)

4.Pinpanikaalam-Masi, Panguni (February, March)

5.Elavenilkaalam -Chithirai, Vaigasi (April, May)

6.Mudhuvenilkaalam-Aani, Aadi (June, July).

Kaba Suram mainly occurs due to variation of Kabam. The period of seasonal aggravation in Kabam is called as Kabam thannilai sirapurum kaalam which exist during the Tamil months Karthigai to Masi (November to February)(8). 


\section{Literature review on Kaba Suram(3).}

Table-1. Classification of symptoms of Kaba Suram according to COVID-19 Stages

S.No Symptoms of Kaba Suram in

Tamil Poetic lines

Analogy with symptoms of various stages of Covid-19

Uncomplicated and mild pneumonia symptoms (COVID-19 stage-1)

\begin{tabular}{|c|c|c|}
\hline 2 & $\begin{array}{l}\text { Thondai nothal, irumal, ilaippu } \\
\text { untaathal, kozhai kakkal }\end{array}$ & $\begin{array}{l}\text { Symptoms of sore throat, cough, expectoration of phlegm, wheeze due to upper } \\
\text { and lower respiratory tract infections. }(11,12)\end{array}$ \\
\hline 3 & $\begin{array}{l}\text { Thalarchi, udal vanmai kuraidhal, } \\
\text { adikkadi kalaithu podhal }\end{array}$ & $\begin{array}{l}\text { Fatigue - a common symptom associated with respiratory illness in COVID-19. } \\
\text { (13) }\end{array}$ \\
\hline 4 & $\begin{array}{l}\text { Malamum neerum kazhidhal, Vayiru } \\
\text { kazhidhal. }\end{array}$ & ACE2 in modulating intestinal inflammation causing diarrhoea.(14) \\
\hline 5 & Neer vetkai & $\begin{array}{l}\text { Dehydration and thirst commonly recognized causes of dehydration may be due to } \\
\text { fever and diarrhoea. (15) }\end{array}$ \\
\hline \multicolumn{3}{|c|}{ Severe Pneumonia (COVID-19 Stage-2) } \\
\hline 6 & $\begin{array}{l}\text { Mael moochu, moochu thinaral, } \\
\text { peru moochu vidal }\end{array}$ & $\begin{array}{l}\text { Breathing difficulty with Diffuse alveolar damage with cellular fibromyxoid } \\
\text { exudates, desquamation of pneumocytes and hyaline membrane formation.(16) }\end{array}$ \\
\hline 7 & Naakku mugam veluthal & $\begin{array}{l}\text { Pallor of tongue, face due to hypoxemia and dyspnoea causing low oxygen } \\
\text { saturation.(17) }\end{array}$ \\
\hline 8 & Oon kollaamai, thookkaminmai & $\begin{array}{l}\text { Poor sleep, loss of appetite may be due to many causes, including cough, excess } \\
\text { mucous production, and frequent arousals from sleep caused by hypercapnia.(18) }\end{array}$ \\
\hline 9 & Vali, udal nonthu & General muscle pain and fatigue are common symptoms of COVID-9.(19,20) \\
\hline \multicolumn{3}{|c|}{ Critical Disease - sepsis, Neurological deficits (COVID-19 STAGE-3) } \\
\hline 10 & Viyarvai & Sweating and vasodilatation due to fever and hypercapnia.(21) \\
\hline 11 & $\begin{array}{l}\text { Achathaiyum manavetrumaiyaiyum } \\
\text { mugathiluntaakkum, kaadhu } \\
\text { yiraithal, kaadhu kaelaamai }\end{array}$ & $\begin{array}{l}\text { Fear and depression (Emotional instability) due to delirium.(17) } \\
\text { Hearing loss and ringing of ears due to } \\
\text { neurological deficits.(22) }\end{array}$ \\
\hline 12 & $\begin{array}{l}\text { Athatti paesuthal, serukku, Vaai } \\
\text { kularal, Nenju ilaguthal, mamam } \\
\text { thuvalal, epporulilum } \\
\text { veruppadaithal }\end{array}$ & $\begin{array}{l}\text { Irrelevant speech a neurological symptom due to replication of the virus in the } \\
\text { brain.(23) }\end{array}$ \\
\hline 13 & Maarbu nothal & $\begin{array}{l}\text { Chest pain or tightness due to myocardial injury resulted due to expression of } \\
\text { ACE2 in cardiac muscles(24) }\end{array}$ \\
\hline 14 & Vikkal & Hiccups may be associated with COVID- 19 pneumonia.(25) \\
\hline 15 & Naachuvaiyariyaamai & $\begin{array}{l}\text { Loss of smell, taste, ataxia and convulsions due to neurological deficits like have } \\
\text { been reported in COVID-19. (23),(26) }\end{array}$ \\
\hline 16 & $\begin{array}{l}\text { Muppini(sanni noi) varuvikkum. } \\
\text { Appothu mandaiyil miguntha soodu, } \\
\text { vaai pithatral, thannilai ariyaamai } \\
\text { undaagum }\end{array}$ & $\begin{array}{l}\text { Delirious stage exhibiting disoriented speech, impaired consciousness due to } \\
\text { invasion of SARS-CoV to some specific brain areas, including the thalamus and } \\
\text { brainstem.(26) }\end{array}$ \\
\hline 17 & Udal veenguthal & $\begin{array}{l}\text { Anasarca due to renal impairment with reduced urine output at sepsis stage of } \\
\text { COVID-19.(27) }\end{array}$ \\
\hline
\end{tabular}

Fig-1. Parallel analysis of humoral pathology of Kaba Suram and stages of COVID-19

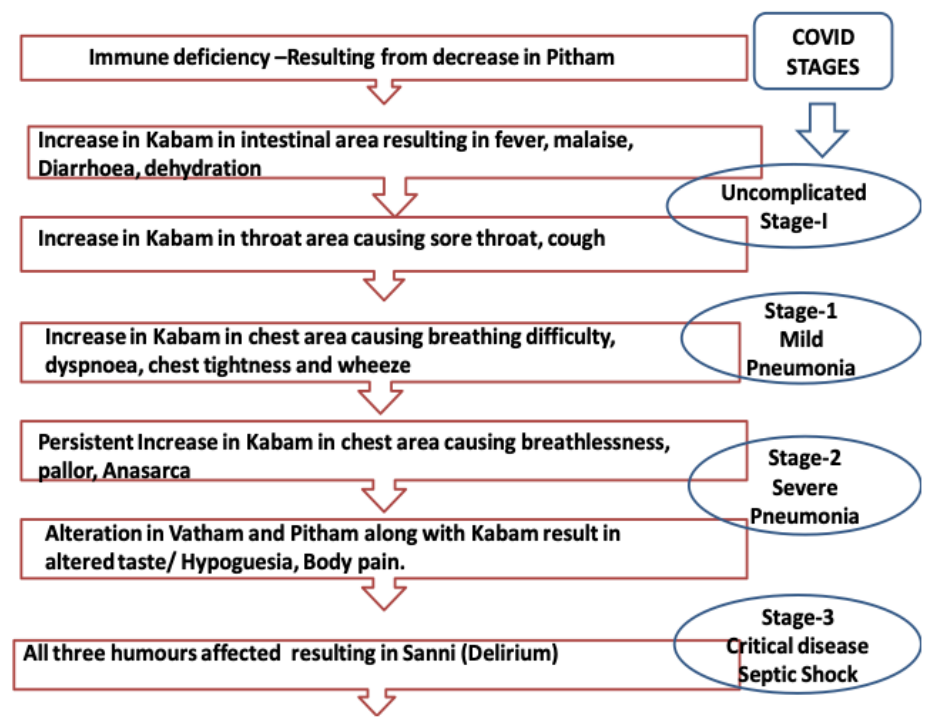


*Vatham, Pitham and Kabam - The three humours are responsible for all the diseases according to the Siddha Pathology. Stepwise alteration of humours have been evaluated and correlated with the stages of COVID-19. (3).

\section{Parallel analysis of humoral pathology of Kaba Suram and stages of COVID-19}

Based on the severity of the disease, the Chinese CDC report divided the clinical manifestations of the COVID-19 as mild, moderate and severe(27).

\section{Uncomplicated Mild disease (COVID-STAGE-1)}

About $81 \%$ of COVID-19 cases are of mild symptoms which may contribute as non-pneumonia and mild pneumonia(27). Patients with mild COVID-19 symptoms present with mild fever, sore throat, dry cough, head ache and muscle pain(17). The Siddha literature on Kaba Suram has also described these symptoms in its Tamil linguistic purism such as Suram (Fever), Thondai nothal (Sore throat), Irumal (Cough), Kozhai kakkal (Expectoration).

Kaḷaippu (Malaise), vali (Muscle pain), Vayiru kazhidhal (diarrhoea) in its literature Suravaagadam (Table-1). Recent researches on COVID-19 suggests that fever with headaches are often the major and initial symptom that may occur early in COVID-19 patients(11,12). The Siddha pathophysiology substantiates this fact, according to which, the Kabam is said to be the foremost humor responsible for fever (Kudal thannil seethamalaathu suram varaathu) which is exhibited on the exterior due to the core pathology(3).

A study conducted in 2019 December also revealed that $98 \%$ of patients had symptoms of fever, $76 \%$ had dry cough, 55\% were presented with dyspnoea, and 3\% had gastrointestinal symptoms of diarrhoea(28). The increase in Kaba humour is manifested in throat area referred in literature as (Kandam) resulting in Thondai nothal (Sore throat), Irumal (Cough), Kozhai kakkal (Expectoration) which are also the symptoms of uncomplicated stage of COVID-19(12,13). Though the symptoms of dyspnoea, and non-respiratory symptoms such as diarrhoea can be rarely observed at the initial stage, however $10 \%$ of patients have been found to present with gastrointestinal symptoms initially (e.g. diarrhoea, nausea), before the manifestation of fever and dyspnoea(29). The event of diarrhoea occurs due to impaired protective immune response which paves way for the entry of infection especially in organs that have high Angiotensinconverting enzyme 2 gene (ACE2) expression. This causes inflammation in digestive tract resulting in diarrhoea(14). This fact highly emphasizes the Siddha pathophysiological concept of aggravation of $\mathrm{kaba}$ humour in the intestine (Kudal thannil seetham) which is the prime cause of fever and the step wise disease progression.

\section{Mild Pneumonia}

A Taiwan case study on the first COVID-19 subject revealed the symptoms of fever, dyspnoea and mild hypoxemia on 10th day of illness and the X-ray chest indicated invading pneumonia, which advanced diffusely later. This study was additionally in comparative with the COVID-19 case study of United states with similar characteristics on day 9 of disease. Both these cases had mild manifestations of Pneumonia(30). This stage can be compared with the symptoms of increase of Kabam in chest area causing Mael moochu, Moochu thinaral ( Dyspnoea), Oon kollaamai (loss of appetite), Thookkaminmai (Insomnia), Kalaitu pothal (fatigue) mentioned in the texts Theran karisal and Suravaagadam (Table-1). The Siddha texts emphasize even the minor symptoms concerned with mild respiratory discomforts that may accompany mild pneumonic stage. Poor sleep complaints are normal in individuals with chronic respiratory illness which may be due to incessant cough, mucous production, and frequent sleep arousals due to hypercapnia(18). Previous research studies have discovered that the Viral flu infection can prompt rhabdomyolysis which might be the reason for general exhaustion and myalgia in COVID-19(19).

\section{Severe Pneumonia (Stage-II)}

This severe stage of pneumonia is associated with severe dyspnoea, tachypnoea, respiratory distress, and hypoxia followed by Acute Respiratory Distress Syndrome (ARDS). Notwithstanding, the indication of fever can be moderate or even missing. This stage can be suggestive of respiratory failure which is associated with pulmonary edema. In Sidddha literature on Kaba Suram,this severe stage of COVID-19 can be well correlated with the persistent severe increase of Kabam in chest area resulting in Mael moochu (Severe dyspnoea), Naakku mugam veluthal (Pallor of tongue and face) as indicated in the text Yugimunivar vaithya chintamani, viyarvai (profuse sweat), uțal vīnkutal (Anasarca) as mentioned in Theran Karisal (Table-1). Viyarvai (profuse sweat) can be produced due to high body temperature(22). Hypercapnia may lead to a lower diffusion of carbon dioxide leading to excessive sweating and vasodilatation (33). The reason behind Pallor of tongue and face as mentioned in Siddha texts may be due to ARDS which is characterized by poor oxygenation resulting on hypoxemia and may also present as central or peripheral cyanosis as a result of hypoxemia. Udal veenguthal (Anasarca) as mentioned in Theran Karisal can occur due to pulmonary edema, renal impairment resulting in reduced output(18).

\section{Critical stage (Stage-III)}

The exaggerated inflammatory response induced by infecting organisms results in critical stage of sepsis. At this stage excessive uncontrolled release of proinflammatory cytokines known as Cytokine storm (CS) plays an important role in the pathogenesis leading to multi organ failure and death $(31,32)$. The patients experience a decrease in oxygen saturation and inflammation-induced lung injury followed by sepsis which is the crucial phase of the disease. The clinical symptoms of COVID-19 at sepsis stage are dyspnoea, hypoxemia, tachycardia, adjusted mental status, hyperbilirubinemia, acidosis, high lactate, coagulopathy, 
and thrombocytopenia. This situation, is related with high mortality, circulatory, and cell/metabolic variations(29) These features of sepsis described in conventional literature in which there is drastic release of proinflammatory mediators causing multiorgan failure and sepsis has been termed as Sanni (Delirious stage) in Siddha texts alerted as the final stage of Kaba suram. At this stage all the three humours Vatham, Pitham and Kabam which are

responsible for the well being of an individual is drastically affected resulting in symptoms of Acham, Manavetrumai (Emotional disturbances of fear and depression), Athatti pesuthal, Vaay Kularal (Irrelevant speech, agitation), Thannilai ariyaamai (Impaired consciousness), Muppini (sanni noi) (Delirious stage due to neurological disorders/brain infections) and Vikkal (Hiccups) (Table-1). Vikkal (Hiccups) though seems like a minor symptom, may be the main presenting symptom of pneumonia.(25). Neurological disorders in COVID-19 has been analysed and concluded through previous research studies. According to these studies, the infection of olfactory neurons in the nose may enable the virus to spread from the respiratory tract to the brain. Infection of endothelial cells may allow the virus to pass from the respiratory tract to the blood and then across the blood-brain barrier into the brain and replication of the virus in brain may cause neurological disorders(23).

Besides these, the Siddha literature on Kaba Suram highlights even the subtle symptoms of COVID-19 as Vaay Thuvarthal, Naachuvai ariyaamai (loss of smell/altered taste) and kaadhu iraidhal and kaadhu kaelaamai (Auditory deficits) (Table-1). A recent research study indicated that out of 82 COVID-19 patients $1.22 \%$ has coincidence of neurosensory hearing loss.(33) The spread of COVID-19 virus to the brain via the cribriform plate may cause other sensory deficits which involve anosmia (loss of smell). Hence the COVID-19-affected patients who exhibit loss of smell and taste are also accompanied with neurological signs and symptoms. (34) Owing to the systemic inflammatory response and immune system disorders during the disease progression the incidence of cardiovascular symptoms is high, in patients with COVID-19. SARS-CoV-2 and MERS-CoV have similar pathogenicity, and the myocardial damage caused by infection with these viruses can cause acute myocarditis and heart failure(24). Hence Maarbu nothal (Chest pain) a symptom of Kaba Suram can be well correlated with the cardiovascular symptom of COVID-19. However, it may also accompany severe lung complications such as pneumonia(35).

\section{Conclusion}

Through this review, the signs and symptoms of Kaba Suram in Siddha literature has been validated and found to be in analogy with various stages of COVID-19 symptoms. Also, the pathophysiological concepts of Kaba Suram has been derived based on Siddha Noi Naadal , Noi Mudhal Nadal (Disease diagnosis from its root cause) and the Mukkutram theory (Trihumoural theory) of COVID-19 has been established. This literature analysis would therefore be supportive to Siddha physicians and research scientists and enable them to opt suitable Siddha formulations based on altered humour to combat COVID-19 according to its stages and severity.

\section{Conflict of Interest None}

\section{Abbreviation:}

KSK- Kaba Sura Kudineer

\section{Funding source}

This research did not receive any specific grant from funding agencies in the public, commercial, or not-for-profit sectors.

\section{Acknowledgements}

The author thankfully acknowledges Prof. Dr. K. Kanakavalli, Director General, Central Council for Research in Siddha (Ministry of AYUSH, Govt. of India), Arumbakkam, Chennai-600106 for her support in carrying out this literature research.

\section{References}

1. Vengatarajan S. Agathiyarrendayiram(Tamil) of Agathiyar.1st ed. Thanjavore; Thanjavur Saraswathi Mahal publication; 2005.51-159p.

2. Srikantha Arunachalam. Treatise on Ayurveda. 1st ed. Nugegoda, Sri Lanka; Vijitha Yapa Publications, Piyasiri printing system; 2004.46-50p.

3. Shanmugavelu. M. Noinadal Noimuthalnadal Thiratu-Part2 (Tamil). $3^{\text {rd }}$ ed. Chennai; Thiruvalar M.L. Printers; 2003.1-33p.

4. Kuppusamy muthaliyar.KN. Siddha Maruthuvampothu (Tamil). 6th ed. Chennai; Department of Indian medicine and Homeopathy publications; 2004.27-30 p.

5. Govintharaj Muthaliyar . Kooshayi swamigal Anugragarathi Anupogavaithya Brahma Ragasiyam(Tamil) of Palanisamymuthaliyar. 1st ed. Madurai: Jeyam print; 1969. 59-83 p.

6. Shanmugavelu M. Noinadal Noimuthalnadal Thiratu -Part 1 (Tamil). 3rd ed. Chennai; Thiruvalar M.L.M printers; 2003, 238-240 p.

7. Vengatarajan S,Dhanvanthrivaithyam of -Part1(Tamil) of Dhanvanthri.1st ed.Thanjavore; Thanjaisaraswathi Mahal noolagam; 1884, 65-95 p.

8. Thurairajan. Noi Illa Neri. Siddha Hygiene and Preventive medicine. Chennai; Authority of the Government of Madras; 1951.55-60 p.

9. Yoogi Munivar. Yoogivaithya Sinthamani. 1st ed. Chennai; Department of Indian medicine and Homeopathy publications; 1998, 42-48 p.

10. Young PJ, Saxena MK. Fever and Anti pyresis in infection. Clinical focus, Med J August 2011; 195; 458-459 p.

11. Wu F, Zhao S, Yu B, Chen YM, Wang W, Song ZG, et al. A new coronavirus associated with human 
respiratory disease in China. Nature 2020; 579;265-285 p.

12. Huang C, Wang Y, Li X, Ren L, Zhao J, Hu Y et al. Clinical features of patients infected with 2019 novel coronavirus in Wuhan, China. Lancet 2020;395;497-506 p.

13. Guo YR, Cao QD, Hong ZS, Tan Y.Y, Chen S.D, Jin HJ, et al. The origin, transmission and clinical therapies on coronavirus disease 2019 (COVID-19) outbreak - an update on the status. Mil. Med. Res 2020; 7:11p.

14. Liang W, Feng Z, Rao S, Xiao C, Xue X, Lin Z et al.Diarrhoea may be underestimated: a missing link in 2019 novel coronavirus. Gut epub ahead of print. Gut 2020; 0;1-3 p.

15. Naila A, Shaheen, Abdulrahman A. Alqahtani, Assiri H, Alkhodair R, et al. Public knowledge of dehydration and fluid intake practices: variation by participants' characteristics. BMC Public Health.2018;18(1);1346 p.

16. Xu Z, Shi L, Wang Y, Zhang J, Huang L, Zhang C, et al. Pathological findings of COVID-19 associated with acute respiratory distress syndrome. Lancet Respir Med 2020; 8:420-22.

17. Cascella M, Rajnik M, Cuomo A, Dulebohn SC, Napoli RD. Features, Evaluation and Treatment Coronavirus (COVID-19). StatPearls Publishing, Treasure Island, FL; 2020; 1-47p.

18. George CF. Perspectives on the management of insomnia in patients with chronic respiratory disorders. Sleep 2000; 23:31-5 p.

19. Ayala E, Kagawa FT, Wehner JH, Tam J, Upadhyay D. Rhabdomyolysis associated with 2009 influenza A(H1N1). J AM MED ASSOC 2009; 302:1863-4 p.

20. Nance JR, Mammen AL. Diagnostic evaluation of rhabdomyolysis. Muscle Nerve 2015;51:793-810 p.
21. Bobbia X, Claret PG, Palmier L, Robert M, Granpierre RG, Roger $\mathrm{C}$ et al. Concordance and limits between transcutaneous and arterial carbon dioxide pressure in emergency department patients with acute respiratory failure: a single-center prospective observational study. Scand. J. Trauma, Resusc. Emerg. Med 2015; 23:77 p.

22. Sriwijitalai W, Wiwanitkit V. Hearing loss and COVID-19: A note. Am J Otolaryngol. 2020 : 102473. doi: 10.1016/j.amjoto.2020.102473

23. Baig AM. Neurological manifestations in COVID19 caused by SARS-CoV-2. Editorial commentary. CNS Neurosci Ther 2020 ;(5):499-501 p. doi: $10.1111 / \mathrm{cns} .13$

24. Zheng YY, Ma YT, Zhang JY, Xie X, et al. COVID-19 and the cardiovascular system, Nat. Rev. Cardiol. 2020;17: 259-260 p.

25. Karakonstantis S, Pitsigavdaki S, Korela D, Galani D. Lower lobe pneumonia presenting as singultus (hiccups).Caspian J Intern Med 2018; 9(4):403-405 $\mathrm{p}$.

26. Ahmad I, Rathore FA. Neurological manifestations and complications of COVID-19: A literature review [published online ahead of print, 2020 May 6]. J Clin Neurosci. 2020; S0967-5868(20)31078-X. doi:10.1016/j.jocn.2020.05.01727.

27. Yi Y, Lagniton PNP, Ye S, Li E, Xu RH. COVID-19: what has been learned and to be learned about the novel coronavirus disease. Int $\mathrm{J}$ Biol Sci. 2020; 16(10):1753-1766. Published 2020 Mar 15. doi:10.7150/ijbs. 4513428 .

28. Wang D, Hu B, Hu C, Zhu F, Liu X, Zhang J, et al. Clinical characteristics of 138 hospitalized patients with 2019 novel coronavirus-infected pneumonia in $\mathrm{Wuhan}$, China. A M E A S S O C 2020;323(11):1061-1069 p. 